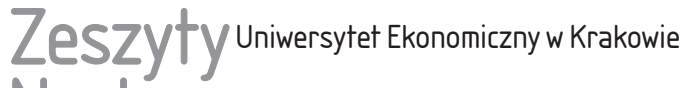 Naukowe
}

\section{The Moderating Role of Perceived Organisational Support in the Relationship between Employees' Entrepreneurial Orientation and Organisational Commitment ${ }^{*}$}

\section{Abstract}

Objective: The purpose of this article is to analyse the moderating role of perceived organisational support (POS) in the relationship between employees' entrepreneurial orientation (EEO) and organisational commitment (OC).

Research Design \& Methods: The research is aimed at determining the role of POS and EEO in explaining differences in employees' commitment to a given organisation. The set

Anna Wójcik-Karpacz, Jan Kochanowski University in Kielce, Żeromskiego 5, 25-369 Kielce, e-mail: anna.wojcik-karpacz@ujk.edu.pl, ORCID: https://orcid.org/0000-0002-6303-6778.

Jarosław Karpacz, Jan Kochanowski University in Kielce, Żeromskiego 5, 25-369 Kielce, e-mail: jaroslaw.karpacz@ujk.edu.pl,ORCID: https://orcid.org/0000-0001-7315-2855.

* The project was funded by the National Science Centre in Poland (funds allocated on the basis of a decision no. DEC-2014/15/B/HS4/04326).

This is an open access article distributed under the terms of the Creative Commons Attribution-NonCommercial-NoDerivatives 4.0 License (CC BY-NC-ND 4.0); https://creativecommons.org/ licenses/by-nc-nd/4.0/ 
of research proposals identifies (1) how employees' entrepreneurial orientation and organisational commitment are related to each another and (2) how the relationship between employees' entrepreneurial orientation and organisational commitment is moderated by perceived organisational support. The method used to carry out the quantitative empirical research was CAWI (Computer Assisted Web Interviews). The conceptual framework for this research was the theory of perceived organisational support. The project was funded by the National Science Centre in Poland (funds allocated on the basis of a decision no. DEC-2014/15/B/HS4/04326).

Findings: The research provides knowledge about entrepreneurial personality in determining employees' commitment to their organisation. At the same time, it identifies the role of POS as a moderator of the EEO-OC relationship.

Implications / Recommendations: The results of the research allow for a better understanding of entrepreneurship and strengthen its theoretical foundations as an individual-level construct that determines organisational commitment. In addition, the description of the moderation effect (POS as a moderating variable) helps to better explain and predict the relationships between EEO and OC. Managers must pay more attention to the supportive organisational environment because of its effect on the strength of employees' entrepreneurial orientation and its impact on their organisational commitment. The research results encourage further analyses on EO in vertical, horizontal and temporal dimensions in various size enterprises and their business profiles.

Contribution: The article presents arguments which enable the recognition of employees' entrepreneurial orientation as a determinant of organisational commitment and adding POS to the list of factors moderating the relationship between employees' entrepreneurial orientation and organisational commitment. In addition, the research proves that the age of employees is positively related to their commitment to the organisation (the older they were, the more committed to the enterprise), while seniority is negatively related to organisational commitment (the more seniority employees had, the less committed they were).

Keywords: employees' entrepreneurial orientation, organisational commitment, perceived organisational support, entrepreneurship.

JEL Classification: M12, M51, L86.

\section{Introduction}

Entrepreneurship is a process used by members of a given organisation who, by using opportunities unnoticed by others, break the boundaries of acceptable behavioural patterns and practices in order to generate new values. These activities can change the organisation in a variety of contexts, including organisational ones. Entrepreneurial orientation (EO), one of the most well-elaborated concepts in the field of entrepreneurship, is the foundation of these changes (Wójcik-Karpacz 2018). EO is manifested within enterprises to such an extent that entrepreneurial attitudes and behaviours "pervade the enterprise at all levels" (Covin \& Slevin 
1991). Thus, the idea of EO becomes an organisationally pervasive phenomenon (Wales, Monsen \& McKelvie 2011). Employees' entrepreneurial orientation (EEO) has been widely recognised by researchers as an enterprise-level construct which determines the enterprise's performance (Koe 2016). But they have paid little attention to how EO manifests itself in organisations at non-organisational levels.

At the root of this cognitive gap lies, among others, an assumption repeatedly adopted by researchers - that EO manifests itself in organisations in a homogeneous manner; however, there are also some researchers who state that EO is heterogeneous. They believe that universal homogeneity serves to obscure much of the variability associated with the manifestation of EO as an organisational phenomenon. Their considerations are based on the assumption that although enterprises may sometimes use a relatively homogeneous distribution of attitudes and behaviours throughout the enterprise, the changing strategic requirements of different organisational levels may result in the need for more heterogeneous manifestation of EO (Wales, Monsen \& McKelvie 2011).

That is why researchers have only recently begun to propose that EO may also be regarded as an individual-level construct (Robinson \& Stubberud 2014). This has brought new areas and levels of and perspectives on EO into focus for researchers to analyse EO, and for employees' entrepreneurial behaviour to be interpreted in various aspects and contexts (Wang et al. 2017). Identifying the role of such contexts is important because it makes it possible to determine the conditions in which the relationship occurs and to distinguish them from the conditions in which it disappears.

Mechanisms explaining how EO contributes to employees' commitment to a given organisation are still being sought, which prompts to undertake the issue of role of moderators and its empirical settlement. These research issues, which determine not only the role of EEO in explaining differences in employees' commitment to their organisation, but also the role of POS as a potential moderator of employee entrepreneurship, form the framework of this article. The purpose of the article is thus to analyse the moderating role of perceived organisational support (POS) in the relationship between employees' entrepreneurial orientation (EEO) and organisational commitment (OC).

\section{Model and Hypotheses}

Since EO operates at the individual level, its relationship with individuals' attitude and behaviour is also worth studying (Krueger \& Sussan 2017). Specifically, the influence that employees' entrepreneurial orientation has on organisational commitment $(\mathrm{OC})$ requires further analysis. 
Organisational commitment is defined as the employee's identification with the organisation and his or her willingness to work for it. In the literature, it is also defined as a psychological force tying the employee to the organisation and making changing one's workplace less attractive (Johnson, Groff \& Taing 2009, Peyrat-Guillard \& Glińska-Neweś 2010) and expresses the attitude of the employee towards the organisation and its goals, a natural consequence of which is an appropriate behaviour of the employee (Lewicka, Karp-Zawlik \& Pec 2017). This is important because commitment to an organisation and its goals has long been considered an important feature for organisational competitiveness. Commitment is a necessary condition so that employees who possess valued capabilities, of which entrepreneurship is one, do not choose to join competing enterprises (Meyer et al. 2002). Building employee commitment is a challenge for human resources departments (Rich, Lepine \& Crawford 2010, Lewicka, Karp-Zawlik \& Pec 2017).

Entrepreneurial employees are characterised as being unconstrained by situational limitations and likely to seek out opportunities to shape their environment by bringing about positive changes. An entrepreneurial personality is a unique dispositional characteristic defined as a behavioural tendency towards undertaking personal initiative in creating a favourable environment (Wang et al. 2017). Entrepreneurial personality may be considered a personal resource, meaning that employees who have an entrepreneurial personality will be more likely to experience high organisational commitment than their less proactive workmates.

Organisational commitment, in turn, is an attitude that reflects the commitment between an employee and an organisation, and suggests a desire to maintain organisational membership (Castanheira \& Story 2016). Those who are highly committed to their organisation are willing to devote more effort, identify themselves more with its values, and seek to maintain their affiliation with the organisation (Marsden, Kalleberg \& Cook 1993). Hence, employees' entrepreneurial orientation may be thought to have the potential to reveal and adapt initiatives related to employees' commitment to the organisation, while increasing their strength at the same time. These considerations have led to the following hypotheses:

\section{Hypothesis 1: Employees' entrepreneurial orientation affects their organisational commitment.}

A supportive organisational environment is believed to have the capacity to create a cheerful and productive workforce because POS fosters employee expectations and cognition that the organisation will provide sufficient job resources when needed. POS is defined as employees' perception that the organisation cares about their well-being and values their contributions (Eisenberger et al. 1986). POS represents "(...) the assurance that aid will be available from the organisation when it is needed to carry out one's job effectively and to deal with stressful 
situations" (Wojtkowska, Andersz \& Czarnota-Bojarska 2016). At the same time, organisational support perceived by employees is not limited to any one specific area of activity in the organisation (Wojtkowska, Andersz \& Czarnota-Bojarska 2016).

In addition, research has established that employees develop perceptions of organisational support because they tend to ascribe their traits or qualities to organisations through a process of "personification". The personification of the organisation by its employee is based on the accumulation of rewards and punishments an employee has received from other more powerful organisation members over time. In addition, in order to improve POS, the employee must perceive the organisation's actions directed at him as discretionary and reflective of positive assessments. Therefore, the employee's history of rewards, which result from various human resource practices and decisions, contributes to perceived organisational support (Wayne, Shore \& Liden 1997). Perceived organisational support, as a resource in the organisation, may cause employees to generate a series of positive emotions thanks to support and understanding from colleagues and supervisors, as well as the affirmation of their abilities (Wang et al. 2005, Zhou et al. 2012).

According to the organisational support theory, when employees perceive that the organisation cares about them, they are more likely to believe that their employer is willing to recognise their efforts and meet their socio-emotional needs (Eisenberger et al. 1986). Therefore, based on the organisational support theory, POS is a potential contextual factor which largely dictates how employees behave in return for being favourably treated by their organisations. Research also shows that POS is positively correlated with employees' organisational commitment (Eisenberger \& Stinglhamber 2011) and manifests in additional personal resources (e.g. self-efficacy, optimism, self-esteem) which greatly facilitate individual OC (Wang et al. 2017).

Given the findings on organisational support theory, it has been proposed that the effect of employees' entrepreneurial orientation on OC is likely to be suppressed when POS is high. This is because all employees, including less entrepreneurial ones, are likely to be engaged and interested in their jobs in a highly supportive organisational environment in which less room is left for EEO to manifest and make a significant difference on OC (Eisenberger et al. 1986). In contrast, in a less supportive organisation, entrepreneurial employees are likely to be more engaged than their less entrepreneurship-oriented workmates through the self-creation process of OC. This leads to the following hypotheses:

Hypothesis 2: POS moderates the relationship between employees' entrepreneurial orientation and organisational commitment in such a way that this relationship will be stronger when POS is low than when it is high. 


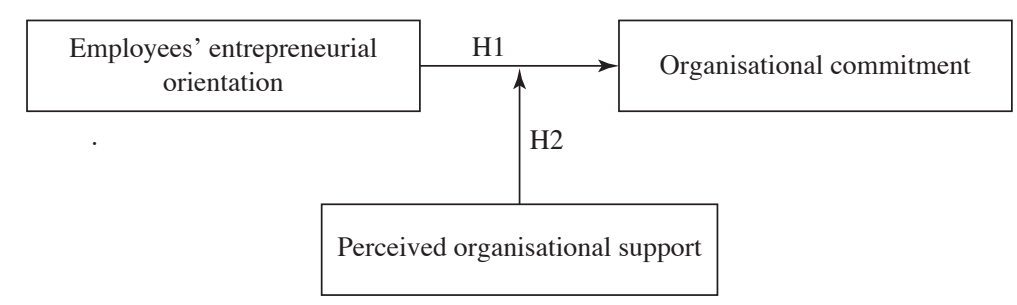

Fig. 1. The Research Model and Hypotheses Source: the authors.

The above discussion is summarised by the research model presented in Figure 1. It presents the constructs and relationships under analysis.

\section{Research Methodology}

\subsection{Sample and Data Sources}

The survey was carried out in November 2017 among employees of a large IT enterprise. Two criteria were used for selecting such an enterprise. The first was pragmatic: management agreed to allow us to conduct empirical research. The second criterion was company size. An enterprise with a large number of employees was preferred.

Top management approved the distribution of questionnaires among employees through an internal communication system (enterprise-owned intranet). E-mails containing an invitation to participate in the survey and a questionnaire to be completed online were sent to 809 of the company's employees. The survey was done twice in order to get more responses (though employees could take the survey only once). 509 employees of the 809 responded, a 63\% completion rate. The 31 questionnaires sent incomplete were removed. The basis for statistical analyses consisted of data collected from 478 respondents, including 117 women and 361 men, which narrowed the research group against the background of the surveyed population to $59 \%$. The average age of employees in the IT enterprise was 31.87 years, with a standard deviation of 5 years. And the average seniority was 4.89 years, with a standard deviation of 3.09.

The CAWI (Computer Assisted Web Interviews) method was used to conduct the quantitative empirical research. Each questionnaire contained the employee's ID number, which was necessary to send each employee the online questionnaire, as well as at subsequent stages of data collection and data processing. 


\subsection{Variables and Measures}

\section{Dependent Variable}

While the reliability of the scales used in the questionnaires had previously been analysed by their authors, the questionnaires used in this empirical research were verified once again. The purpose of testing the reliability of scales was to verify whether the reliability of the questionnaire, in the analysed sample, was similar to that provided by its authors, and whether the selection of the sample did not affect the reliability of the questionnaire itself.

Organisational commitment (OC) played the role of dependent variable. The items measuring OC were taken from the scale designed by P. V. Marsden, A. L. Kalleberg and C. R. Cook (1993). The measurement of organisational commitment consists of six items which ask employees to rate how much effort they are willing to make for the organisation, as well as their belief in and acceptance of the organisation's goals and values, while taking the desire to maintain membership in the organisation into account (Marsden, Kalleberg \& Cook 1993). Employees indicated their agreement on the items on a 7-point Likert scale ranging from "strongly disagree" (1) to "strongly agree" (7).

The first reliability analysis carried out showed a moderate Cronbach alpha coefficient value $(\alpha=0.696)$, while statistical analysis after deleting the item containing "I feel very little loyal to this organisation (reverse-coded)", indicated an increase in the scale's internal reliability. The final version of the scale uses the remaining five points. The Cronbach's alpha coefficient for the final scale was 0.714 . Therefore, a complex measure of organisational commitment was created by calculating the average value of five indicators. Factor analysis was then performed using the Mplus 8.1 for MAC program. Exploratory factor analysis (EFA), meanwhile, is a method using the main components with Varimax rotation (Kaiser score) carried out on a shortened 5-point scale. The EFA showed that this construct is unidimensional (measure of sampling adequacy $=0.758$; Bartlett's test of sphericity: approx Chi-Square $=502,446, d f=10, p<0.001)$. Finally, the statistic Kaiser-Meyer-Olkin (K-M-O) Measure of Sampling Adequacy indicates the proportion of variance in variables, which may be caused by underlying factors. The K-M-O indicator adopted a value of 0.1 .

For referential purposes, H. F. Kaiser added the following values to the results: 0.00 to 0.49 unacceptable; 0.50 to 0.59 miserable; 0.60 to 0.69 mediocre; 0.70 to 0.79 middling; 0.80 to 0.89 meritorious; 0.90 to 1.00 marvellous (Cerny \& Kaiser 1977). In general, high values (close to 1.0) indicate that the factor analysis may be useful for data processing. If the value is less than 0.50 , probably the results of the factor analysis may not be suitable for data processing. Thus, the higher the value 
of this indicator, the stronger the basis for using the factor analysis in assessing relationships among observable variables.

\section{Independent Variable}

In this article, employees' entrepreneurial orientation (EEO) is an independent variable. The Covin and Slevin's scale (1989) was adopted because a measurement model and measurement items (i.e. a nine-item operationalisation of the EO construct) refer to the use of the EO construct in various contexts (George \& Marino 2011). Employees indicated their agreement to these items on a 7-point Likert scale ranging from "strongly disagree" (1) to "strongly agree" (7). All of the EEO items loaded into the EEO factor were above 0.70. The Cronbach's alpha coefficient for the final scale was 0.727 . As a result, EEO was measured by the average of nine items. Moreover, a confirmatory factor analysis confirmed the number of entrepreneurial dimensions to be used - it was the three suggested in the literature: innovativeness ( 3 items), proactiveness ( 3 items), and risk taking (3 items). Each measurement item was loaded into the corresponding dimension at a satisfactory level of statistical significance. This confirmed the three-dimensional structure of entrepreneurial orientation among the enterprise's employees.

\section{Moderator}

Perceived organisational support is, in turn, a moderator variable. Employees completed a shortened version of the survey on perceived organisational support (SPOS), with nine items of the SPOS scale used. These were loaded the highest in the factor analysis (Eisenberger et al. 1986). The shortened version of the SPOS has been used elsewhere (Eisenberger, Fasolo \& Davis-LaMastro 1990, Wayne, Shore \& Liden 1997). Employees indicated their agreement to these items on a 7-point Likert scale ranging from "strongly disagree" (1) to "strongly agree" (7). Hence, organisational commitment was measured by the mean value of nine 7-point Likert scale items (Cronbach's $\alpha=0.900$ ).

Afterwards, the exploratory factor analysis was conducted using the main components with Varimax rotation (Kaiser score): Kaiser-Meyer-Olkin Measure of Sampling Adequacy $=0.913$; Bartlett's test of sphericity: approx Chi-Square $=$ $=2372,598 ; d f=36 ; p>0.001$. One factor explained $57.031 \%$ of the variability in perceived organisational support, which was a satisfactory value. In general, the results showed the measures to be strongly reliability and convergent.

\section{Control Variables}

The research used two control variables - employee age and seniority, the latter measured by the years the employee had been working at the enterprise up until November 2017, when the surveys were completed. 


\section{Results}

\section{Descriptive Statistics and Correlations}

In the next step, Pearson's linear correlation analysis was performed and the structural equations modelled in order to assess the relationship among variables (in SPSS for MAC and MPlus 8.1 for MAC programmes, respectively). To calculate the Pearson's linear correlation, meta-variables were calculated as mean values of individual issues included in the questionnaire. Descriptive statistics and correlations between variables are presented in Table 1 .

Table 1. Statistics and Correlations between Variables

\begin{tabular}{|l|c|c|c|c|c|c|c|}
\hline \multicolumn{1}{|c|}{ Specification } & 1 & 2 & 3 & 4 & 5 & 6 & 7 \\
\hline $\begin{array}{l}\text { Organisational } \\
\text { commitment }\end{array}$ & 1 & & & & & & \\
\hline Innovativeness & $0.247^{* *}$ & 1 & & & & & \\
\hline Proactiveness & $0.311^{* *}$ & $0.555^{* *}$ & 1 & & & & \\
\hline Risk-taking & $211^{* *}$ & $0.225^{* *}$ & $0.257^{* *}$ & 1 & & & \\
\hline $\begin{array}{l}\text { Perceived organisational } \\
\text { support }\end{array}$ & $0.575^{* *}$ & $0.261^{* *}$ & $0.306^{* *}$ & $0.193^{* *}$ & 1 & & \\
\hline Age & $0.181^{* *}$ & 0.042 & 0.041 & $0.180^{* *}$ & $0.104 *$ & 1 & \\
\hline Work experience & -0.086 & -0.079 & $-0.111^{*}$ & $0.172^{* *}$ & -0.036 & $0.195^{* *}$ & 1 \\
\hline Mean & 4.5464 & 5.016 & 5.4888 & 4.8577 & 5.1674 & 31.8666 & 4.8945 \\
\hline Standard deviation & 0.96998 & 0.94576 & 0.99345 & 1.21476 & 0.97312 & 4.99792 & 3.08653 \\
\hline
\end{tabular}

$N=478$; significant correlation at the level of $p<0.05 ; * *$ significant correlation at the level of $p<0.01$.

Source: the authors.

The analysis of mean levels and standard deviations led to the conclusion that employees assess their organisational commitment as high (4.54 on a 1-7 point scale). At the same time, they rate the level of risk-taking (4.86 on average) higher, and innovativeness even much higher (5.016 on average). Proactiveness was rated as the highest (5.49 on average). Perceived organisational support was also highly rated, indicating a positive perception of the activities undertaken by the organisation towards its employees (5.16 on average). Standard deviations ranged from $0.9-1.2$, which indicates a moderate dispersion of responses in the fields analysed.

The analysis of the correlations among the variables showed that all three dimensions of employees' entrepreneurial orientation were significantly related to their organisational commitment, and this relationship had a positive direction. 
However, correlation coefficients showed the relationships to be only of moderate strength. However, there was a strong correlation between organisational commitment and perceived organisational support (0.575), and its direction indicated that there was a strong and growing correlation between these two variables. Also, the results of correlation analysis indicated that all three dimensions of employees' entrepreneurial orientation were significantly and positively related, and these relationships are moderately strong (from 0.225 to 0.555 ). Similarly, significant relationships existed between perceived organisational support and the dimensions of employees' entrepreneurial orientation (the correlation ranged from 0.193 to 0.306 ).

\section{Statistical Analysis and Research Findings}

Structural equation modelling was performed to assess the relationship among variables and to verify hypotheses. The results of estimation of three dependence models are presented in Table 2. The first, a control model, presents the relationships among control variables and a key dependent variable - organisational commitment. The second model presents the relationships between employees' entrepreneurial orientation and organisational commitment, taking into account EEO, which for the purposes of the analysis was treated as a second-level reflective latent variable. In particular, the first level consisted of three EEO dimensions defining the level of 9 indicators, while the second was EEO as a latent construct defining the level of three EEO dimensions. Thus, EEO was treated as a reflective-reflective variable. In the third model, perceived organisational support was included in the analysis as a moderator (treated as a reflective variable defining 9 indicators).

Indicators for model 1 and 2 suitability, i.e.: RMSEA (Root Mean Square Error of Approximation) $=$ accordingly: $0.059 ; 0.058$ (values below 0.06 are considered a sign of good suitability of theoretical and empirical models), CFI (Compound Fit Index) $=$ accordingly: $0.962 ; 0.913$ ) and TLI (Tucker-Lewis Index) = accordingly: 0.937; 0.891 (here values above 0.9 are considered a sign of good suitability of theoretical and empirical models). This indicated an overall high level of estimation and good suitability between the conceptual model and the structural model. Model 3 (presented in Table 2) was estimated on the basis of Akaike Information Criteria (AIC), which for model 3 was 33665.702. Models with lower AICs should be considered better suited than models with higher AICs. Lower AICs mean better predictive values of the model (Burnham \& Anderson 2004, pp. 261-304). Although the AIC levels for model 3 are higher than for models 1 and 2, indicating a weaker, though nonetheless acceptable fit. This model explains $62.2 \%$ of data variability $\left(R^{2}=0.622\right)$. 
Table 2. Results of Estimation of Dependency Models between Employees' Entrepreneurial Orientation and Organisational Commitment in the Context of Perceived Organisational Support

\begin{tabular}{|c|c|c|c|}
\hline Specification & Model 1 & Model 2 & Model 3 \\
\hline \multicolumn{4}{|c|}{ Adjustment measurements } \\
\hline RMSEA & 0.059 & 0.058 & $\mathrm{n} / \mathrm{a}^{*}$ \\
\hline Compound Fit Index & 0.962 & 0.913 & $\mathrm{n} / \mathrm{a}^{*}$ \\
\hline Tucker-Lewis Index & 0.937 & 0.891 & $\mathrm{n} / \mathrm{a}^{*}$ \\
\hline Akaike Information Criteria & 7912.727 & 21702.391 & 33665.702 \\
\hline $\begin{array}{l}\text { Degree of dependent } \\
\text { variable explanation }\left(R^{2}\right)\end{array}$ & 0.035 & 0.261 & 0.622 \\
\hline \multicolumn{4}{|c|}{ Model parameters (dependent variable - organisational commitment) ${ }^{* *}$} \\
\hline Employee's age & $0.021(0.007 ; 0.002)$ & $0.018(0.007 ; 0.008)$ & $0.009(0.005 ; 0.072)$ \\
\hline Work experience & $-0.023(0.011 ; 0.032)$ & $-0.014(0.010 ; 0.182)$ & $-0.010(0.008 ; 0.200)$ \\
\hline $\begin{array}{l}\text { Employees' entrepreneurial } \\
\text { orientation (EEO) }\end{array}$ & - & $0.502(0093 ; 0.000)$ & $0.207(0.061 ; 0.001)$ \\
\hline $\begin{array}{l}\text { Perceived organisational } \\
\text { support (POS) }\end{array}$ & - & - & $0.445(0.055 ; 0.000)$ \\
\hline \multicolumn{4}{|c|}{ Moderation effects (moderator: perceived organisational support)** } \\
\hline $\begin{array}{l}\text { EEO x POS (relationship } \\
\text { between EEO and POS) }\end{array}$ & - & - & $-0.078(0.034 ; 0.024)$ \\
\hline
\end{tabular}

$N=478$; * due to how model 3 was estimated, it was not possible to provide RMSEA, CFI and TLI values; in this case, the model 3 adjustment measurement is AIC (Akaike Information Criteria). The lower the value, the better the level of model adjustment measurement; ** such values as regression model estimation parameter, standard estimation errors and ( $p$-value) significance level are respectively provided in brackets.

Source: the authors.

The analysis of the models presented in Table 2 leads to several conclusions. Firstly, the models' level of estimation (their adjustment measurement) was satisfactory. This indicates that the theoretical relationships are well-mapped in the empirical research results. Secondly, the level of organisational commitment explanation increased when subsequent variables were introduced into the model; moreover, the $R^{2}$ coefficient in the second model was over 0.26 , indicating a relatively high impact of employee entrepreneurial orientation on organisational commitment. And in the third model, taking the effect of moderation into account, the level of organisational commitment explanation was, at over $60 \%$, already very high. This proves that there was a strong relationship between perceived organisational support and organisational commitment. Finally, the $R^{2}$ coefficient has increased, but only because model 3 describes more variables. To avoid overfitting, 
an effort is made to reduce the model based on the AIC criterion. This ultimately yields the final version of model 3, which is included in Table 2 (Hawkins 2004).

Thirdly, while the control variables were significant in the first model, they only slightly explain the variability of the dependent variable (they have a small, though statistically significant impact on organisational commitment). It is worth noting that the older the employee, the more attached they were to the organisation (coefficient in the regression model $=0.021 ; p=0.002$ ), while the more senior an individual was in the organisation, the less committed they were to the organisation (coefficient in the regression model $=-023.0 ; p=0.032$ ). In the second model, only the employees' age was positively related to organisational commitment, while the level of dependence remained at the same level (coefficient in the regression model $=0.018 ; p=0.008$ ). In the third model, however, neither age (coefficient in the regression model $=0.009 ; p=0.072$ ) nor seniority (coefficient in the regression model $=-0.010 ; p=0.200$ ) were significant for organisational commitment. This shows that the introduction of variables, i.e. employees' entrepreneurial orientation and perceived organisational support, reduced the impact of two control variables on organisational commitment to a statistically insignificant level.

Fourthly, employees' entrepreneurial orientation appears to be an important determinant of organisational commitment (see model 2; coefficient in the regression model $=0.502 ; p=0.000$ ), which shows that there were no grounds for rejecting Hypothesis 1. Thus, the higher the level of the employee's entrepreneurial orientation, the higher the level of organisational commitment.

Fifthly, perceived organisational support was significantly and positively related to organisational commitment (see model 3; coefficient in the regression model = $=0.445 ; p=0.000$ ). What is more, it was also a statistically significant moderator of the relationship between employees' entrepreneurial orientation and organisational commitment (see model 3; coefficient in the regression model $=-0.078 ; p=0.024$ ). Therefore, there were no grounds to reject Hypothesis 2.

To learn more about the nature of this relationship, it is worth using the moderation graph (see Fig. 2).

Analysis of Figure 2 indicates that at high levels of perceived organisational support (POS), organisational commitment (CO) levels were significantly higher, and higher levels of employee entrepreneurial orientation (EEO) corresponded to higher organisational commitment (OC) levels. A similar impact on the level of organisational commitment could be observed when perceived organisational support was low, but in this case the importance of employees' entrepreneurial orientation for perceived organisational support was greater than when perceived organisational support was high. However, higher levels of employee entrepreneurial orientation corresponded to higher levels of perceived organisational support. Although these differences were relatively small, they were statistically 


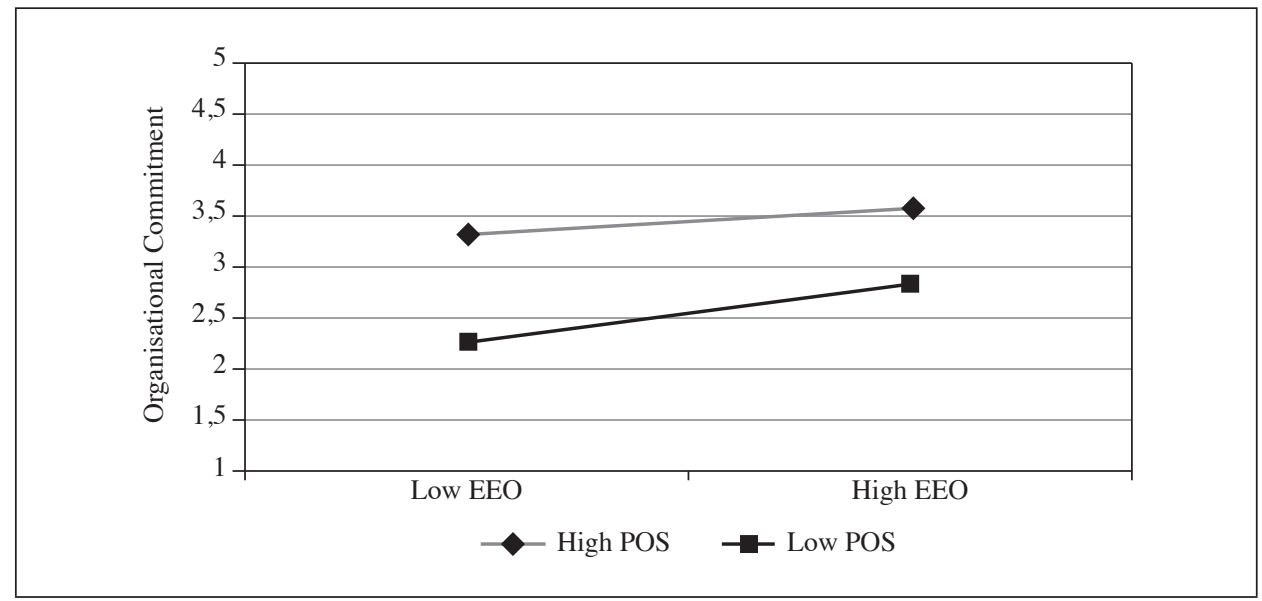

Fig. 2. Effect of Moderation of Perceived Organisational Support on the Relationship between Employees' Entrepreneurial Orientation and Organisational Commitment Source: the authors.

significant, as indicated by the value of the moderation coefficient and its level of significance (see Table 2; coefficient in the third model was $-0.078 ; p=0.024$ ). Therefore, there were no grounds to reject Hypothesis 2. Indeed, POS moderates the relationship between employees' entrepreneurial orientation and organisational commitment in such a way that this relationship will be stronger when POS is low than when it is high.

\section{Conclusions}

The research has provided new insight into employees' entrepreneurial orientation as an individual factor differentiating the organisational commitment among employees. At the same time, it was established that POS is an important moderator of the employee entrepreneurial orientation-organisational commitment relationship.

When perceived organisational support is low, the importance of employees' entrepreneurial orientation in raising the level of organisational commitment increases. That is because higher levels of employee entrepreneurial orientation correspond to higher levels of organisational support.

This means that EEO will be better expressed and will better predict organisational commitment in a less supportive organisational environment (low POS) than in a more supportive one (high POS). 
Considering the consequences of POS on the strength of the impact of employees' entrepreneurial orientation on their commitment to the organisation, management responsible for developing human resources in the enterprise should pay particular attention to issues related to POS. Its first step should be to identify high and low POS levels (i.e. vertically across hierarchy levels, horizontally across business units, and temporally as an organisation develops) and take appropriate action to improve or maintain existing POS levels.

\section{Bibliography}

Burnham K. P., Anderson D. R. (2004), Multimodel Inference: Understanding AIC and BIC in Model Selection, "Sociological Methods \& Research", vol. 33, no 2, https://doi. org/10.1177/0049124104268644.

Castanheira F., Story J. (2016), Making Good Things Last Longer: The Role of Savoring on the Relationship between HRM and Positive Employee Outcomes, "Human Resource Management", vol. 55, no 6, https://doi.org/10.1002/hrm.21704.

Cerny C. A., Kaiser H. F. (1977), A Study of a Measure of Sampling Adequacy for Factor-analytic Correlation Matrices, "Multivariate Behavioral Research", vol. 12, no 1, https://doi.org/10.1207/s15327906mbr1201_3.

Covin J. G., Slevin D. P. (1989), Strategic Management of Small Firms in Hostile and Benign Environments, "Strategic Management Journal", vol. 10, no 1, https://doi. org/10.1002/smj.4250100107.

Covin J. G., Slevin D. P. (1991), A Conceptual Model of Entrepreneurship as Firm Behavior, "Entrepreneurship Theory and Practice", vol. 16, no 1, https://doi.org/10.1177 /2F104225879101600102.

Eisenberger R., Fasolo P., Davis-LaMastro V. (1990), Perceived Organizational Support and Employee Diligence, Commitment, and Innovation, "Journal of Applied Psychology", vol. 75, no 1, https://doi.org/10.1037/0021-9010.75.1.51.

Eisenberger R., Huntington R., Hutchison S., Sowa D. (1986), Perceived Organizational Support, "Journal of Applied Psychology", vol. 71, no 3, https://psycnet.apa.org/ doi/10.1037/0021-9010.71.3.500.

Eisenberger R., Stinglhamber F. (2011), Perceived Organizational Support: Fostering Enthusiastic and Productive Employees, American Psychological Association, Washington, DC.

George B. A., Marino L. (2011), The Epistemology of Entrepreneurial Orientation: Conceptual Formation, Modeling, and Operationalization, "Entrepreneurship Theory and Practice", vol. 35, no 5, https://doi.org/10.1111/2Fj.1540-6520.2011.00455.x.

Hawkins D. M (2004), The Problem of Overfitting, "Journal of Chemical Information and Modeling", vol. 44, no 1, https://doi.org/10.1021/ci0342472.

Johnson R. E., Groff K. W., Taing M. U. (2009), Nature of the Interactions among Organizational Commitments: Complementary, Competitive or Synergistic?, "British Journal of Management", vol. 20, no 4.

Koe W. L. (2016), The Relationship between Individual Entrepreneurial Orientation (IEO) and Entrepreneurial Intention, "Journal of Global Entrepreneurship Research", vol. 6, no 13, https://doi.org/10.1186/s40497-016-0057-8. 
Krueger N., Sussan F. (2017), Person-level Entrepreneurial Orientation: Clues to the "Entrepreneurial Mindset”?, "International Journal of Business and Globalisation", vol. 18, no 3, https://doi.org/10.1504/IJBG.2017.10003130.

Lewicka D., Karp-Zawlik P., Pec M. (2017), Organizational Trust and Normative Commitment, "Annales Universitatis Mariae Curie-Sklodowska", vol. LI, no 3.

Marsden P. V., Kalleberg A. L., Cook C. R. (1993), Gender Differences in Organizational Commitment: Influences of Work Position and Family Roles, "Work and Occupations", vol. 20, no 3, https://doi.org/10.1177/2F0730888493020003005.

Meyer J. P., Stanley D. J., Herscovitch L., Topolnytsky L. (2002), Affective, Continuance, and Normative Commitment to the Organization: A Meta-analysis of Antecedents, Correlates, and Consequences, "Journal of Vocational Behavior", vol. 61, no 1, https:// doi.org/10.1006/jvbe.2001.1842.

Peyrat-Guillard D., Glińska-Neweś A. (2010), Positive Organizational Potential, Organizational Commitment and Organizational Citizenship Behavior: A French/Polish Comparison, "Journal of Positive Management", vol. 1, no 1.

Rich B. L., Lepine J. A., Crawford E. R. (2010), Job Engagement: Antecedents and Effects on Job Performance, "Academy of Management Journal", vol. 53, no 3, https://doi. org/10.5465/amj.2010.51468988.

Robinson S., Stubberud H. A. (2014), Elements of Entrepreneurial Orientation and Their Relationship to Entrepreneurial Intent, "Journal of Entrepreneurship Education", vol. 17, no 2 .

Wales W., Monsen E., McKelvie A. (2011), The Organizational Pervasiveness of Entrepreneurial Orientation, "Entrepreneurship Theory and Practice", vol. 35, no 5, https:// doi.org/10.1111\%2Fj.1540-6520.2011.00451.x.

Wang H., Law K. S., Hackett R. D., Wang D., Chen Z. X. (2005), Leader-member Exchange as a Mediator of the Relationship between Transformational Leadership and Followers' Performance and Organizational Citizenship, "Academy of Management Journal", vol. 48, no 3, https://doi.org/10.12691/education-2-9-14.

Wang Z., Zhang J., Thomas C. L., Yu J., Spitzmueller Ch. (2017), Explaining Benefits of Employee Proactive Personality: The Role of Engagement, Team Proactivity Composition and Perceived Organizational Support, "Journal of Vocational Behavior", vol. 101, https://doi.org/10.1016/j.jvb.2017.04.002.

Wayne S. J., Shore L. M., Liden R. C. (1997), Perceived Organizational Support and Leader-member Exchange: A Social Exchange Perspective, "Academy of Management Journal", vol. 40, no 1, https://doi.org/10.2307/257021.

Wojtkowska K., Andersz N., Czarnota-Bojarska J. (2016), Adapting the Survey of Perceived Organizational Support, "Polish Journal of Applied Psychology", vol. 14, no 4.

Wójcik-Karpacz A. (2018), Wszechobecność organizacyjna orientacji przedsiębiorczej: identyfikacja poziomów i jednostek analizy, "Zarządzanie i Finanse. Journal of Management and Finance", vol. 16, no 1/1.

Zhou L., Wang M., Chen G., Shi J. (2012), Supervisors' Upward Exchange Relationships and Subordinate Outcomes: Testing the Multilevel Mediation Role of Empowerment, "Journal of Applied Psychology", vol. 97, no 3, https://doi.org/10.1037/a0026305. 


\section{Moderująca rola postrzeganego wsparcia organizacyjnego w relacji między orientacją przedsiębiorczą pracowników a przywiązaniem organizacyjnym} (Streszczenie)

Cel: Celem artykułu jest zbadanie moderującej roli postrzeganego wsparcia organizacyjnego (perceived organisational support - POS) w relacji między orientacją przedsiębiorczą pracowników (employees' entrepreneurial orientation - EEO) a przywiązaniem organizacyjnym (organisational commitment - OC).

Metodyka badań: Badania mają na celu określenie roli POS i EEO w wyjaśnianiu różnic w przywiązaniu do organizacji pomiędzy pracownikami. Propozycje badawcze pozwalają określić: 1) jak orientacja przedsiębiorcza pracowników i przywiązanie organizacyjne są ze sobą powiązane oraz 2) jak relacja pomiędzy orientacją przedsiębiorczą pracowników a przywiązaniem organizacyjnym jest moderowana przez postrzegane wsparcie organizacyjne. Metodą stosowaną do przeprowadzenia ilościowych badań empirycznych był CAWI (Computer Assisted Web Interviews). Ramy koncepcyjne tych badań to teoria postrzegania wsparcia organizacyjnego. Projekt został sfinansowany przez Narodowe Centrum Nauki w Polsce (środki przydzielone na podstawie decyzji nr DEC-2014/15/B/HS4/04326).

Wyniki badań: Badanie dostarcza wiedzy na temat roli osobowości przedsiębiorczej w określaniu przywiązania pracowników do organizacji, jednocześnie wskazuje rolę POS jako moderatora relacji EEO-OC.

Wnioski: Rezultaty badania umożliwiają lepsze zrozumienie przedsiębiorczości i wzmocnienie jej teoretycznych podstaw jako konstruktu na poziomie indywidualnym, który determinuje przywiązanie organizacyjne. Ponadto opis efektu moderacji (postrzegane wsparcie organizacyjne jako zmienna moderująca) pozwala lepiej wyjaśniać i przewidywać relacje pomiędzy orientacją przedsiębiorczą pracowników i przywiązaniem organizacyjnym. Menedżerowie muszą zwracać większą uwagę na wspierające środowisko organizacyjne ze względu na jego wpływ na siłę oddziaływania orientacji przedsiębiorczej pracowników na ich przywiązanie organizacyjne. Wyniki badań wskazują, że należy kontynuować badania nad orientacją przedsiębiorczą wewnątrz organizacji w wymiarze pionowym, poziomym i czasowym w różnych rozmiarach przedsiębiorstw i ich profilach biznesowych.

Wkład w rozwój dyscypliny: Badanie dostarcza wiedzy na temat osobowości przedsiębiorczej i jej wpływu na przywiązanie pracowników do organizacji. Jednocześnie wskazuje ono rolę postrzeganego wsparcia organizacyjnego jako moderatora relacji między orientacją przedsiębiorczą pracowników i przywiązaniem organizacyjnym. W artykule przedstawiono argumenty, które pozwalają uznać orientację przedsiębiorczą pracowników za determinantę przywiązania organizacyjnego oraz uwzględnić postrzeganie wsparcia organizacyjnego wśród czynników moderujących relację między orientacją przedsiębiorczą pracowników a przywiązaniem organizacyjnym. Dowiedziono ponadto, że wiek pracowników jest pozytywnie powiązany z ich przywiązaniem do organizacji, natomiast staż pracy w organizacji jest negatywnie powiązany z przywiązaniem organizacyjnym.

Słowa kluczowe: orientacja przedsiębiorcza pracowników, przywiązanie organizacyjne, postrzeganie wsparcia organizacyjnego, przedsiębiorczość. 